\title{
INHERITED AND ACQUIRED FACTORS IN RESISTANCE TO INFECTION
}

\author{
I. Development of Resistant and Susceptible Lines of Mice \\ Through Selective Breeding*
}

By LESLIE T. WEBSTER, M.D.

(From the Laboratories of The Rockefeller Institute for Medical Research)

(Received for publication, October 14, 1932)

Resistance of the host to infection, although generally regarded as the resultant of both inherited and acquired forces, has been studied most intensively from the viewpoint of the acquired elements which develop from contact of host and microorganism. Recently, however, the less defined influences associated with heredity and environment have been made subject to experimental study.

Geneticists have shown that controlled lines of plants have definite and different amounts of resistance which are inherited. They have observed $(1,2)$ that intercurrent infections may be more prevalent in some lines of animals than in others housed under similar conditions. They have injected large doses of specific bacteria parenterally into birds and rodents and by breeding from survivors have developed lines increasingly resistant to these injections (1924 to 1933) (3-8). It is not clear, however, that these test animals have been free from the infections studied and from specific immunity factors which could conceivably have developed and invalidated the findings completely. Moreover, it has not been shown that the observed differences in reaction of the animals to the artificial injections are related to differences in resistance to the natural infections.

In 1922 there were developed in this laboratory inbred lines of mice suitable for investigation in that they were proved to have had no exposure to the infections under study and to possess no acquired immunity. Moreover, a technique of infection was developed which was controlled and yet reproduced closely all phenomena of the natural disease. Some lines of the mice proved consistently more and some less susceptible to experimental $B$. aertrycke (9) and B. enteritidis

* The author is indebted to Dr. M. R. Irwin for procuring special strains of mice, for formulating a modified Steenbock ration, and for assistance in developing the breeding stock, to Mrs. K. B. Liedke and Miss A. Johnson for assistance in carrying on the work, and to Drs. C. Lynch and J. Gowen for helpful criticisms of results. 
(10) mouse typhoid, and the susceptible lines suffered a higher mortality than the resistant lines when exposed to herd infections $(10,11)$. In addition, the progeny of individuals surviving experimental $B$. aertrycke mouse typhoid proved more resistant to this infection and to mercury bichloride poisoning than the progeny of unselected mice, and conversely, the progeny of individuals succumbing early to the infection proved more susceptible to mouse typhoid and to bichloride poisoning (12).

The experiments suggested, therefore, that there are inherited factors in resistance which affect the course of infection profoundly.

A study of the relative importance of inherited and acquired factors in determining the outcome of infection has now been undertaken. In preface to this, it was necessary to determine quantitatively, if possible, the relative amounts of resistance inherent in given animal lines. The present paper deals with the findings. By repeated selections from the hybrid Rockefeller Institute line of albino mice, which showed a 37.4 per cent mortality to natural $B$. enteritidis mouse typhoid infection under standardized conditions, lines with approximately 15 and 85 per cent mortalities respectively were developed, and by selections from numerous other closely inbred lines of mice, two lines, with mortalities of 89.0 and 97 per cent, were obtained. A line with 89 per cent fatality, when mated with a line with 15 per cent fatality, gave $F_{1}$ progeny with 17.7 per cent mortality, which when back-crossed with the high and low mortality lines gave evidence of segregation of susceptibility and resistance factors according to heredity. It was demonstrated, furthermore, that under these controlled conditions the response of animals to the infectious organisms was determined by the amount of resistance which they had inherited. The findings will now be described in detail.

\section{Technique}

Source of Mice.-Rockefeller Institute, white-face, black-and-tan, black, spotted, agouti, hairless, Bagg, dwarf, and pink-eye strains have been used in this study. The R. I. mice came from the main Rockefeller Institute breeding room; the others were obtained by M. R. Irwin from the Bussey Institution. The former have been pen inbred for 18 years; the latter brother and sister inbred for at least 12 generations. All were tested several times for the presence of mouse typhoid bacilli in their stools before being admitted to the breeding room.

Maintenance of Breeding Room.-The breeding room isolated from other animal quarters is used exclusively for the rearing of these mice. The attendants devote 
their entire services to the colony. Temperature is thermostatically controlled at $72^{\circ}$. Floor and walls are washed and wiped weekly with 5 per cent lysol. Racks with five shelves hold the standardized, galvanized iron cages. Bedding consists of autoclaved pine shavings. Cages are cleaned weekly by soaking in $\mathbf{5}$ per cent lysol and scrubbing with soap and water. These measures have proved successful in keeping out intercurrent infections. The diet, put into clay cups every 2 nd day, consists of a modified Steenbock formula suggested by M. R. Irwin-yellow cornmeal, 64 per cent; linseed oil meal, 16 per cent; crude casein, 5 per cent; ground alfalfa, 2 per cent; powdered milk, 5 per cent; wheat germ, 10 per cent; yeast, 2 per cent; sodium chloride, 0.5 per cent; calcium carbonate, 0.5 per cent; cod liver oil, 2 per cent; water is available in drop bottles. All mice are identified by ear clippings. Matings are made when mice are 3 months old, one male to four females. Toward the end of the gestation period, the pregnant dams are removed to fresh individual boxes. The number of young born is recorded. When they are 4 weeks old they are separated according to sex and assembled six to eight per box. The dam is returned to the proper breeding box. Weight of young at 4 and 8 weeks is recorded.

Methods of Experimental Infection.-Mice are given the test bacteria when 2 to 3 months old. An 18 hour broth culture of $B$. enteritidis is diluted in broth to contain $5,000,000$ organisms per $0.5 \mathrm{cc}$. This volume of diluted culture is administered by silver catheter intrastomachally to each individual. The animals are then placed in individual glass battery jars containing shavings, food cups, and water, and kept in a special room. This procedure incites an infection which simulates the spontaneous one epidemiologically, clinically, and pathologically.

Technique of Selective Breeding Experiments.-The selective breeding of R. I. mice was carried out in the following manner. 500 females were mated at random with 100 males. The young were weaned at 4 weeks. At this time the parents were given the standard dose of $B$. enteritidis. In instances in which both parents died within 10 days after infection, the progeny were reserved as the susceptible stock. Subsequent matings were made, brother to sister. In instances in which both parents survived the infection, the progeny were injected. If all progeny survived, the surviving parents were tested twelve times for the presence of $B$. enteritidis in their stools. Those persistently negative were mated again. In instances in which two tested litters survived, a third litter was obtained and reserved as the resistant stock. Matings were then made brother to sister. Subsequently, the eslablished breeding stock and all progeny have consisted of animals never exposed to infection. Further selections have been made entirely on the basis of the progeny test; that is, of per cent mortality of two litters and fertility of sire and dam. In the case of the susceptible lines, animals were discarded if two litters showed a mortality less than 80 per cent, and in the case of the resistant lines, a mortality greater than 20 per cent. The tests were made at the first of each month. At the same time 50 unselected mice, raised under identical conditions, were likewise tested as controls. The same mouse strain of $B$. enteritidis (10) has been employed throughout, 
observed carefully, and kept under uniform conditions at ice box temperature. In so far as can be determined, the strain has not altered.

It is important to restate that the colony of about 3,500 mice is continually tested for the presence of mouse typhoid and other intercurrent infections. The progeny of susceptible, resistant, and other lines are housed together at random, six to eight per cage, after weaning, for at least 4 weeks, and no infection takes place. Many samples of normal mice are sacrificed and cultured at autopsy. Carrier tests on all breeding stock are made as routine. The death rate of mice more than 1 week old is less than 0.1 per cent per month. All mice found dead are autopsied and cultured. The stock has apparently remained free of infection.

Maintenance of Unselected Contral Mice.-Housed with selected mice and kept under identical conditions are the breeding stock and litters of the unselected R. I. mice. Some are bred brother to sister; some are pen inbred.

Technique of Selecting Additional Susceptible Lines.-Mice from the Bussey Institution were bred brother and sister until sufficient accumulated for testing. Selections were made according to the results of the progeny test. The mice were tested at the same time as the selected and control R. I. mice with the same culture and under the same conditions.

\section{Selection of Susceptible and Resistant Lines}

Table I and Text-fig. 1 show the crude data of per cent mortality of twenty-six tests on a total of 771 unselected, 2,942 selected susceptible, and 2,265 selected resistant Rockefeller Institute mice. In each test the sets of mice, brought up under identical conditions and of the same age, received the stated dilution of the same culture. Prior to August, 1931, all received the same dose; later the susceptible batches received a smaller and the resistant a larger dose than the unselected batches. The only known variable which could account for the differences in mortality is heredity. The seventeen tests on the unselected mice given $5,000,000 \mathrm{~B}$. enteritidis resulted in a mean mortality with its standard error of $37.4 \pm 1.6$ per cent. The value of $L$ according to the method which Irwin has described (7), as developed from Lexis, Fisher, and Wallace and Snedecor, is 0.932 , and $\chi^{2}$ and $P$ according to Fisher (13), 14.8 and 0.55 , indicating that the differences in results of different tests conform to normal expectancy and that a suitable control of variables in the technique had been achieved.

In each test the mortality of the unselected mice was less than that of the selected susceptible and greater than that of the selected resistant mice. The ranges of mortality of the different lines overlap slightly but the differences as judged by the sum of $\chi^{2}$ s of tests are 


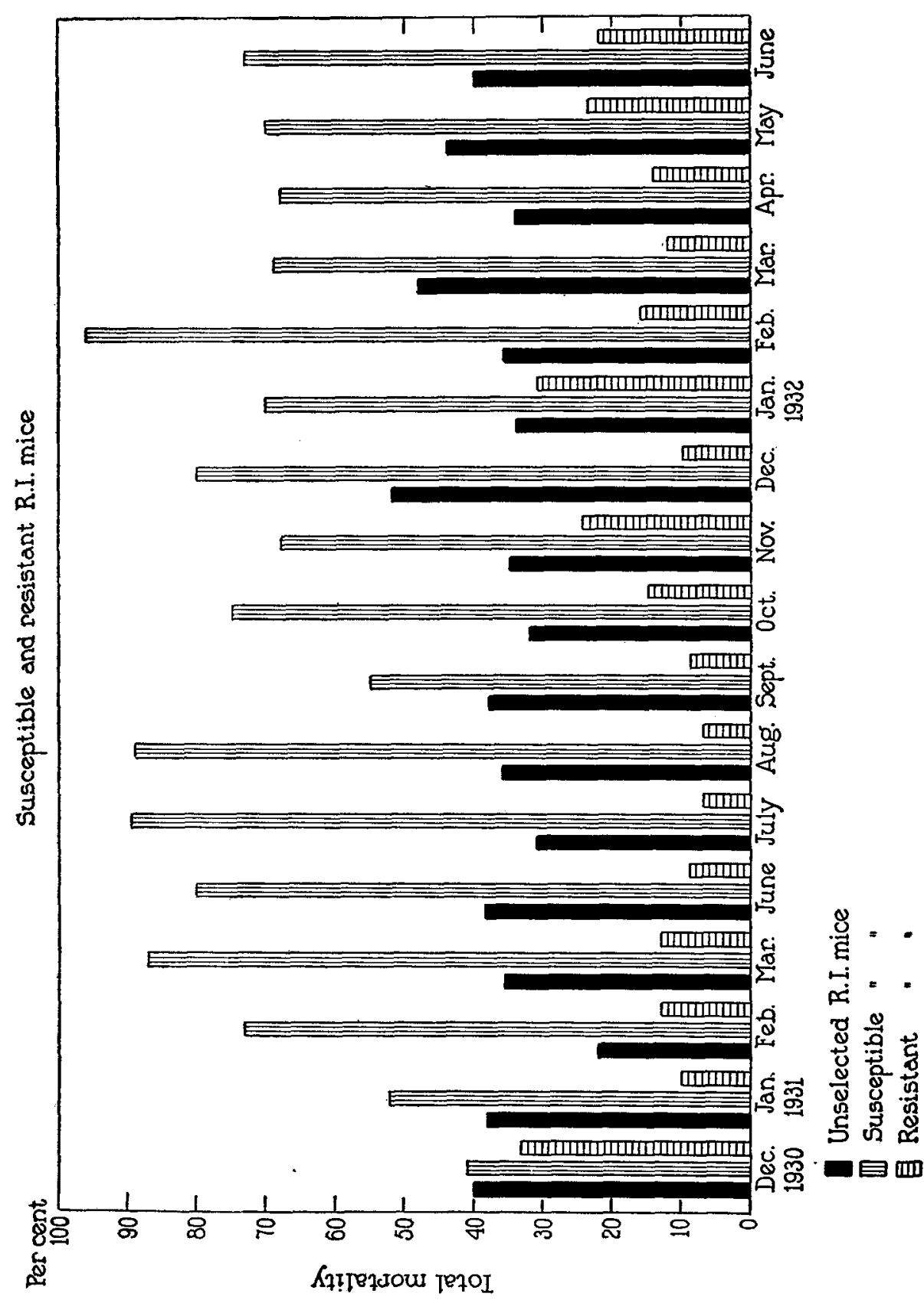


TABLE I

Comparative Mortalities of Unselected and All Selected Susceptible and Resistant Rockefeller Institute Lines Following Inirastomachal Instillation of B. enteritidis Mouse Typhoid

\begin{tabular}{|c|c|c|c|c|c|c|c|c|c|c|c|c|}
\hline \multirow[b]{2}{*}{ Date } & \multicolumn{4}{|c|}{ Unselected mice } & \multicolumn{4}{|c|}{ Susceptible mice } & \multicolumn{4}{|c|}{ Resistant mice } \\
\hline & 莒 & 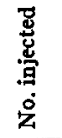 & 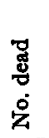 & 苟 & 总 & 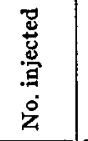 & 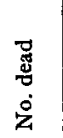 & 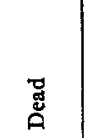 & 莒 & 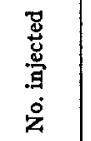 & $\begin{array}{l}\vec{g} \\
\dot{y} \\
\dot{0} \\
\dot{z}\end{array}$ & 芯 \\
\hline 1930 & & & & $\begin{array}{l}\text { per } \\
\text { cent }\end{array}$ & & & & $\begin{array}{l}\text { per } \\
\text { cent }\end{array}$ & & & & $\begin{array}{l}\text { per } \\
\text { cent }\end{array}$ \\
\hline Aug. & & & & & $6^{*}$ & 106 & 48 & 45.2 & 6 & 23 & 1 & 4.3 \\
\hline Sept. & & & & & 6 & 267 & 133 & 49.8 & 6 & 6 & 0 & 0.0 \\
\hline Oct. & & & & & 6 & 229 & 121 & 52.8 & 6 & 16. & 0 & 0.0 \\
\hline Nov. & & & & & 6 & 217 & 100 & 46.0 & 6 & 29 & 4 & 13.8 \\
\hline $\begin{array}{l}\text { Dec. } \\
\quad 1931\end{array}$ & 6 & 52 & 21 & 40.3 & 6 & 167 & 68 & 40.7 & 6 & 24. & 8 & 33.3 \\
\hline Jan. & 6 & 45 & 17 & 37.7 & 6 & 27 & 14 & 51.8 & 6 & 31 & 3 & 9.6 \\
\hline Feb. & 6 & 55 & 12 & 21.8 & 6 & 48 & 35 & 72.9 & 6 & 51 & 7 & 13.7 \\
\hline Mar. & 6 & 53 & 19 & 35.8 & 6 & 111 & 97 & 87.3 & 6 & 67 & 7 & 10.4 \\
\hline May 5 & & & & & 6 & 278 & 256 & 92.0 & 6 & 122 & 14 & 11.5 \\
\hline 8 & & & & & 6 & 139 & 122 & 87.7 & 6 & 136 & 18 & 13.2 \\
\hline June & 6 & 26 & 10 & 38.5 & 6 & 143 & 115 & 80.4 & 6 & 121 & 11 & 9.1 \\
\hline July & 6 & 29 & 9 & 31.0 & 6 & 6 & 6 & 100.0 & 6 & 18 & 3 & 16.7 \\
\hline & & & & & 5 & 99 & 69 & 69.6 & 7 & 67 & 8 & 11.9 \\
\hline Aug. & 6 & 50 & 18 & 36.0 & 6 & 44 & 39 & 88.6 & 6 & 29 & 2 & 6.9 \\
\hline & & & & & 5 & 86 & 70 & 81.3 & 7 & 56 & 3 & 5.3 \\
\hline Sept. & 6 & 21 & 8 & 38.0 & 4 & 67 & 37 & 55.2 & 7 & 100 & 9 & 9.0 \\
\hline Oct. 1 & 6 & 47 & 15 & 31.9 & & & & & & & & \\
\hline & & & & & 4 & 23 & 8 & 34.7 & 7 & 133 & 8 & 6.0 \\
\hline 15 & & & & & 5 & 162 & 122 & 75.3 & 7 & 139 & 22 & 15.8 \\
\hline Nov. & 6 & 48 & 17 & 35.4 & & & & & & & & \\
\hline & & & & & 5 & 154 & 105 & 68.1 & 7 & 151 & 37 & 24.5 \\
\hline $\begin{array}{l}\text { Dec. } \\
\quad 1932\end{array}$ & 6 & 50 & 26 & 52.0 & 5 & 59 & 47 & 79.6 & 7 & 171 & 16 & 9.3 \\
\hline Jan. & 6 & 50 & 17 & 34.0 & 5 & 76 & 53 & 69.7 & 7 & 52 & 16 & 30.7 \\
\hline Feb. & 6 & 51 & 18 & 35.2 & 6 & 26 & 25 & 96.1 & 6 & 48 & 8 & 16.6 \\
\hline Mar. & 6 & 50 & 24 & 48.0 & 5 & 93 & 64 & 68.8 & 7 & 8 & 1 & 12.5 \\
\hline Apr. & 6 & 47 & 16 & 34.0 & 5 & 154 & 105 & 68.2 & 7 & 201 & 29 & 14.4 \\
\hline May & 6 & 50 & 22 & 44.0 & 5 & 44 & 31 & 70.4 & 7 & 152 & 36 & 23.7 \\
\hline June & 6 & 47 & 19 & 40.4 & 5 & 117 & 86 & 73.5 & 7 & 114 & 25 & 21.9 \\
\hline Totals. & & 771 & & & & 2,942 & & & & 2,265 & & \\
\hline
\end{tabular}

$* 5 \times 10^{6}$. 
significant. Further comparisons of the mice are made on the basis of selection.

Susceptible Lines.-The first selection of susceptibles (Table II) was made by choosing the litters of unselected sires and dams, both of which had died 1 to 10 days after injection (see Technique). These

TABLE II

Susceptible Lines of Rockefeller Institute Mice. Results of Progeny Tests Following First Selection

Progeny of Selected Parents Dying 1 to 10 Days after Injection

\begin{tabular}{|c|c|c|c|c|c|c|}
\hline \multirow{2}{*}{$\begin{array}{c}\text { Line } \\
\text { identification }\end{array}$} & \multirow{2}{*}{$\begin{array}{c}\text { Sire } \\
\text { identification }\end{array}$} & \multirow{2}{*}{ No. dams } & \multicolumn{4}{|c|}{ Progeny tested } \\
\hline & & & No. litters & No. progeny & No. dead & Dead \\
\hline & & & & & & per cent \\
\hline 1 & 223.0 & 7 & 24 & 136 & 119 & 87.5 \\
\hline A & 288.0 & 6 & 11 & 52 & 45 & 86.5 \\
\hline 2 & 158 & 4 & 11 & 59 & 43 & 72.8 \\
\hline 3 & 127 & 6 & 20 & 105 & 74 & 70.4 \\
\hline B & 3.0 & 4 & 12 & 64 & 47 & 73.4 \\
\hline C & 277 & 6 & 8 & 43 & 31 & 72.0 \\
\hline D & 356.6 & 7 & 14 & 57 & 40 & 70.1 \\
\hline $\mathbf{E}$ & 404 & 6 & 13 & 57 & 40 & 70.1 \\
\hline $\mathbf{F}$ & 86.0 & 4 & 6 & 38 & 26 & 68.4 \\
\hline G & 330.1 & 6 & 13 & 78 & 47 & 60.2 \\
\hline $\mathbf{H}$ & 140 & 7 & 23 & 127 & 73 & 57.5 \\
\hline $\mathbf{I}$ & 81.0 & 7 & 13 & 87 & 49 & 56.3 \\
\hline 4 & 106 & 8 & 27 & 120 & 56 & 46.7 \\
\hline 5 & 356.0 & 5 & 16 & 122 & 61 & 50.0 \\
\hline $\mathrm{J}$ & 330.2 & 9 & 16 & 98 & 48 & 49.0 \\
\hline $\mathbf{K}$ & 226 & 5 & 12 & 68 & 32 & 47.0 \\
\hline $\mathbf{L}$ & 59 & 6 & 14 & 77 & 27 & 35.0 \\
\hline $\mathbf{M}$ & 256.0 & 5 & 7 & 41 & 12 & 29.3 \\
\hline Total... & 18 & 108 & 260 & 1,429 & 870 & 60.9 \\
\hline
\end{tabular}

litters, $S_{1}$, or possible lines, eighteen in number, never exposed to infection, were then mated brother to sister and otherwise for progeny tests. From 7 to 27 litters containing 38 to 136 progeny were obtained from each line and tested. The average mortality of the 1,429 progeny from all lines was 60.9 per cent, significantly greater than that of the unselected control mice, 37.4 per cent. ${ }^{1}$ The progeny mortalities of

${ }^{1} \chi^{2}$ tests for significance of differences are given in Table VII. 
the several lines ranged from 87.5 to 29.3 per cent, and were significantly greater than the average mortality of the unselected mice, except in the cases of Lines $4, \mathrm{~K}, \mathrm{~L}$, and $\mathrm{M}$.

The second selection was made (Table III) by discarding all but five of the eighteen lines of the first selection, together with individuals in the five selected lines which by the progeny test were least susceptible. From the five selected lines further second generation progeny were obtained $\left(\mathrm{S}_{2}\right)$ and mated brother to sister. Their offspring were

TABLE III

Susceptible Lines of Rockefeller Institule Mice. Resulls of Progeny Tests Following Second and Third Selections

\begin{tabular}{|c|c|c|c|c|c|c|c|c|c|c|c|c|c|}
\hline \multicolumn{7}{|c|}{ Second selection } & \multicolumn{7}{|c|}{ Third selection } \\
\hline \multirow{2}{*}{ 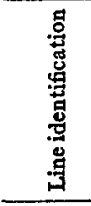 } & \multirow[b]{2}{*}{ 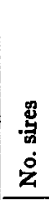 } & \multirow[b]{2}{*}{ 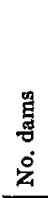 } & \multicolumn{4}{|c|}{ Progeny tested } & \multirow{2}{*}{ 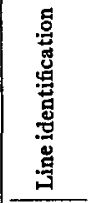 } & \multirow[b]{2}{*}{$\begin{array}{l}\text { 昜 } \\
\dot{0} \\
\dot{2}\end{array}$} & \multirow[b]{2}{*}{ 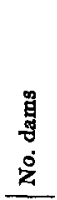 } & \multicolumn{4}{|c|}{ Progeny tested } \\
\hline & & & 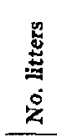 & 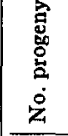 & $\begin{array}{l}\vec{J} \\
\text { v } \\
\dot{0} \\
z\end{array}$ & 丞 & & & & $\begin{array}{l}\text { 总 } \\
\text { 总 } \\
\dot{0} \\
z\end{array}$ & $\begin{array}{l}\text { 总 } \\
\text { 品 } \\
\text { 足 } \\
\dot{0} \\
\dot{z}\end{array}$ & $\begin{array}{l}\overrightarrow{8} \\
\dot{8} \\
\dot{0} \\
\dot{z}\end{array}$ & 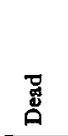 \\
\hline & & & & & & $\begin{array}{l}\text { per } \\
\text { cent }\end{array}$ & & & & & & & $\begin{array}{l}\text { per } \\
\text { cent }\end{array}$ \\
\hline 1 & 3 & 10 & 18 & 72 & 60 & 83.3 & 1 & 11 & 34 & 65 & 295 & 258 & 87.5 \\
\hline 2 & 2 & 7 & 22 & 97 & 81 & 83.5 & 2 & 4 & 18 & 31 & 167 & 146 & 87.4 \\
\hline 3 & 2 & 7 & 24 & 124 & 96 & 77.4 & 3 & 4 & 17 & 15 & 82 & 65 & 79.3 \\
\hline 4 & 3 & 8 & 20 & 95 & 74 & 77.9 & 4 & 3 & 12 & 9 & 50 & 24 & 48.0 \\
\hline $3 \times 4$ & 1 & 4 & 13 & 58 & 40 & 68.9 & $3 \times 4$ & 2 & 7 & 7 & 29 & 24 & 82.7 \\
\hline 5 & 5 & 25 & 45 & 271 & 125 & 46.1 & 5 & 1 & 3 & 3 & 20 & 14 & 70.0 \\
\hline $1 \times 5$ & 1 & 2 & 3 & 20 & 8 & 40.0 & $1 \times 2$ & 3 & 9 & 9 & 47 & 34 & 72.3 \\
\hline otals. & 17 & 63 & 145 & 737 & 484 & 65.5 & & 29 & 104 & 143 & 720 & 593 & 82.3 \\
\hline
\end{tabular}

then tested, two litters from each dam as stated above. The average mortality of progeny of all lines, 145 litters, totaling 737 mice, was 65.7 per cent as compared to 60.9 in the first selection. This difference is significant. The mortality of progeny of Line 4 was likewise notably higher. However, the mortalities of progeny of lines showing highest mortality on the first test (Lines 1, 2, and 3), together with Line 5, did not differ significantly from those of the first selection. The susceptible Line 1, with 83.3 per cent mortality, crossed with the less susceptible Line 5, with 46 per cent mortality, gave three litters, 
totaling twenty mice with a mortality of 40 per cent, suggesting dominance of resistance.

In the third selection (Table III), the five lines were retained but less susceptible individuals, as determined by the testing of two litters, were discarded (see Technique). Additional litters were secured from the selected susceptibles $\left(\mathrm{S}_{3}\right)$ and brother to sister matings made. The mortality of all progeny from the third selection lines was greater (Table III), 82.3 per cent, than that of progeny from the second selection lines, 65.5 per cent. The third selection increased the mortalities of Lines 4 and 5 significantly but had no appreciable effect on Lines 1 , 2 , and 3 .

TABLE IV

Susceptible Lines of Rockefeller Institute Mice. Results of Progeny Tests Following Fourth Selection

\begin{tabular}{|c|c|c|c|c|c|c|c|}
\hline \multirow{2}{*}{$\begin{array}{c}\text { Line } \\
\text { identification }\end{array}$} & \multirow{2}{*}{ No. sires } & \multirow{2}{*}{ No. dams } & \multicolumn{5}{|c|}{ Progeny tested } \\
\hline & & & Dose & No. litters & No. mice & No. dead & Dead \\
\hline \multirow{5}{*}{1} & & & & & & & per cent \\
\hline & 16 & 76 & $5 \times 10^{6}$ & 10 & 60 & 51 & 85.0 \\
\hline & & & $5 \times 10^{5}$ & 9 & 38 & 34 & 89.5 \\
\hline & & & & 24 & 129 & 96 & 74.4 \\
\hline & & & $5 \times 10^{4}$ & 9 & 43 & 26 & 60.4 \\
\hline \multirow[t]{2}{*}{2} & 8 & 35 & $5 \times 10^{6}$ & 1 & 6 & 6 & 100.0 \\
\hline & & & $10^{5}$ & 24 & 124 & 112 & 90.3 \\
\hline $1 \times 2$ & 1 & 5 & $10^{5}$ & 3 & 18 & 16 & 88.8 \\
\hline Totals. . & 25 & 116 & & 80 & 418 & 341 & 81.5 \\
\hline
\end{tabular}

In the fourth selection (Table IV), all but Lines 1 and 2 were discarded. Further elimination of less resistant and sterile individuals resulted in a choice of 16 fourth generation sires and 76 dams of Line 1 and 8 sires and 35 dams of Line 2, $\mathrm{S}_{4}$. Brother to sister matings were made, and from Line 1, 52 litters, totaling 270 progeny, were obtained and tested, and from Line 2, 25 litters, totaling 130 progeny. The dosage of $B$. enteritidis was decreased in order to make the basis for selection more rigid. The mortality following the standard instillation of $5,000,000$ bacilli was 85.0 per cent; following 500,000 bacilli, 1/10th the standard dose, 89.5 per cent; following 100,000 bacilli, 74.4 
per cent; following 50,000 bacilli, 1/100th of the standard dose, 60.4 per cent.

The fifth selection was made by choosing the fourth generation sires and dams whose progeny had proved most susceptible to the small test doses of $B$. enteritidis and obtaining further fifth generation litters, $S_{5}$, for breeding. 19 sires and 48 dams were secured from Line 1 and 16 sires and 39 dams from line 2. Brother to sister matings were made as usual. 270 progeny, 54 litters, from Line 1, and 197 progeny, 41 litters, from Line 2, were given a test injection of 100,000 B. enteritidis, $1 / 50$ th of the usual standard dose. The mortality of all progeny, 76.6 per cent, did not differ significantly from that of progeny of the

TABLE V

Susceptible Lines of Rockefeller Institute Mice. Results of Progeny Tests Following Fifth and Sixth Selections

\begin{tabular}{|c|c|c|c|c|c|c|c|}
\hline \multirow{2}{*}{$\begin{array}{l}\text { Line } \\
\text { identifi- } \\
\text { cation }\end{array}$} & \multirow{2}{*}{ No. sires } & \multirow{2}{*}{$\begin{array}{c}\text { No. } \\
\text { dams }\end{array}$} & \multicolumn{4}{|c|}{ Progeny tested } & \multirow{2}{*}{ Remarks } \\
\hline & & & $\begin{array}{l}\text { No. } \\
\text { litters }\end{array}$ & $\begin{array}{c}\text { No. } \\
\text { progeny }\end{array}$ & $\begin{array}{l}\text { No. } \\
\text { dead }\end{array}$ & Dead & \\
\hline & & & & & & per cent & \\
\hline 1 & 19 & 48 & 54 & 270 & 215 & 79.6 & Fifth selection, 100,000 or- \\
\hline 2 & 16 & 39 & 41 & 197 & 143 & 72.6 & ganisms per mouse \\
\hline 1 & 6 & 12 & 12 & 74 & 61 & 82.4 & $\begin{array}{l}\text { Sixth selection, } 100,000 \text { or } \\
\text { ganisms per mouse }\end{array}$ \\
\hline
\end{tabular}

fourth selection, 82.2 per cent, receiving a like dose of $B$. enteritidis (Table V). In Line 1 there was no change, but in Line 2 there occurred a decrease in mortality. This inconsistency is discussed later.

The sixth selection was carried out in a similar manner. At present progeny tests are complete on six sires and twelve dams, the sixth generation $\left(\mathrm{S}_{6}\right)$ of Line 1 . The mortality of twelve seventh generation litters, totaling 74 mice, 82.4 per cent, following the test injection of 100,000 bacilli (Table V), was not significantly different from that of the sixth generation progeny, 79.6 per cent.

Resistant Lines (Table VI).-The first selection was made by choosing survivors of 600 unselected mice, given $B$. enteritidis, whose litters in turn likewise survived injection. The chosen animals and their subsequent progeny were free of the infection, as proved by re- 
peated tests (see Technique). Three sires and twenty-four dams were chosen $\left(R_{1}\right)$, constituting three possible lines. Matings were made and subsequent litters tested. The mortality of the total 138 tested was significantly less, 20.1 per cent, than that of the unselected mice, 37.4 per cent. The mortality of Lines 1 and 3 proved significantly less, 16

TABLE VI

Resistant Lines of Rockefeller Institute Mice. Results of Progeny Tests Following First, Second, and Third Selections

\begin{tabular}{|c|c|c|c|c|c|c|c|c|}
\hline \multirow{2}{*}{$\begin{array}{c}\text { Line } \\
\text { identification }\end{array}$} & \multirow{2}{*}{$\begin{array}{c}\text { Sire } \\
\text { identifi- } \\
\text { cation }\end{array}$} & \multirow{2}{*}{ No. sires } & \multirow{2}{*}{$\begin{array}{c}\text { No. } \\
\text { dams }\end{array}$} & \multicolumn{4}{|c|}{ Progeny tested } & \multirow{2}{*}{ Remarks } \\
\hline & & & & $\begin{array}{c}\text { No. } \\
\text { litters }\end{array}$ & $\left|\begin{array}{c}\text { No. } \\
\text { progeny }\end{array}\right|$ & $\begin{array}{l}\text { No. } \\
\text { dead }\end{array}$ & Dead & \\
\hline & & & & & & & per cent & \\
\hline 1 & 87 & 1 & 8 & 18 & 75 & 12 & 16.0 & First selection, \\
\hline 2 & 71 & 1 & 12 & 7 & 34 & 11 & 32.35 & $5,000,000$ organ- \\
\hline 3 & 8 & 1 & 4 & 6 & 30 & 5 & 16.6 & isms per mouse \\
\hline Totals.... & & 3 & 24 & 31 & 139 & 28 & 20.1 & \\
\hline 1 & & 10 & 42 & 86 & 460 & 42 & 9.1 & Second selection, \\
\hline 2 & & 4 & 14 & 16 & 80 & 16 & 20.0 & $5,000,000$ organ- \\
\hline 3 & & 1 & 3 & 1 & 6 & 4 & 66.6 & isms per mouse \\
\hline Totals.. & & 15 & 59 & 103 & 546 & 62 & 11.3 & \\
\hline 1 & & 32 & 134 & 142 & 833 & 130 & 15.6 & Third selection, \\
\hline 2 & & 4 & 13 & 19 & 119 & 12 & 10.1 & $\begin{array}{l}50,000,000 \text { organ- } \\
\text { isms per mouse }\end{array}$ \\
\hline Totals.... & & 36 & 147 & 161 & 952 & 142 & 14.8 & \\
\hline 1 & & 23 & 88 & 90 & 511 & 91 & 17.8 & Fourth selection, \\
\hline 2 & & 4 & 15 & 20 & 84 & 13 & 15.5 & $\begin{array}{l}50,000,000 \text { organ- } \\
\text { isms per mouse }\end{array}$ \\
\hline Totals... . & & 27 & 103 & 110 & 595 & 104 & 17.5 & \\
\hline
\end{tabular}

per cent, than that of the unselected mice; that of Line 2 did not differ markedly, 32.35 per cent.

The second selection was made within these lines by saving subsequent uninjected litters $\left(R_{2}\right)$ from the parents whose previous progeny had survived the tests. Brother to sister matings were then made and progeny tested. The mortality of the total 546 proved significantly less, 11.3 per cent, than that of the progeny of the first 
selection mice, 20.1 per cent (Table VI). The mortalities of Lines 1 and 2 , however, were not significantly different. The one litter of Line 3 tested showed a 66.6 per cent mortality. In the third selection, Line 3 and relatively susceptible individuals of Lines 1 and 2 were discarded. Further litters $\left(R_{3}\right)$ were obtained from the selected individuals and brother to sister matings made as usual. The progeny were given ten times the standard dose of organisms to increase the rigidity of selection. The result of tests on 142 litters, totaling 833 mice, from 32 sires and 134 dams of Line 1, was an average mortality of 15.6 per cent, and on 19 litters, totaling 119 mice, from 13 dams and 4 sires of Line 2, an average mortality of 10.1 per cent (Table VI). These figures cannot be compared with those of the previous selection because of the different doses of $B$. enteritidis employed.

The fourth selection was made by saving sires and dams whose litters had survived the large dose of organisms. From them, additional fourth generation litters were obtained $\left(\mathrm{R}_{4}\right)$ and mated brother to sister. From 23 sires and 88 dams of Line 1, 90 litters, totaling 511 mice, were tested with the dose of 50,000,000 organisms. The average mortality was 17.8 per cent. From 4 sires and 15 dams of Line 2, 20 litters, totaling 84 mice, were tested. The average mortality was 15.5 per cent (Table VI). These results do not differ significantly from those of the third selection.

To determine whether the differences in percentage mortality of progeny accompanying selection are explainable theoretically on the basis of chance, the $\chi^{2}$ test (13) was employed. The results are given in Table VII. The first selection for susceptibility and for resistance resulted in lines differing significantly from the unselected stock, $-S_{1}$ with $\mathrm{U}, \mathrm{R}_{1}$ with $\mathrm{U}, P=<0.01$. Some selected lines with intermediate percentage mortality, susceptible Line 4 , which did not differ significantly from that of the unselected stock, $P=0.06$, showed significant changes on repeated selection; some lines, on the other hand, with maximum or minimum percentage mortalities, susceptible Lines 1 and 2 , and resistant Lines 1 and 2 which differed significantly from that of the unselected stock, $P=<0.01$, showed no significant changes on further selection.

The homogeneity of selected lines was tested by evaluating the uniformity of percentage mortality among litters according to the 
TABLE VII

Effect of Selection on Mortality to B. enteritidis

\begin{tabular}{|c|c|c|c|}
\hline \multirow{2}{*}{ Stocks compared } & \multirow{2}{*}{ Mortality } & \multicolumn{2}{|c|}{ Significance of differences } \\
\hline & & $\chi^{2}$ & $P$ \\
\hline & per cent & & \\
\hline $\begin{array}{r}\text { Susceptible all lines } \mathrm{S}_{1}{ }^{*} \ldots \ldots \ldots \ldots \ldots \ldots \ldots \\
\text { with } \mathrm{U}_{\dagger} \ldots \ldots \ldots \ldots \ldots \ldots \ldots\end{array}$ & $\begin{array}{l}60.9 \\
37.4\end{array}$ & 112.0 & $<0.01$ \\
\hline $\begin{array}{r}\text { Susceptible all lines } \mathbf{S}_{2} \ldots \ldots \ldots \ldots \ldots \ldots \ldots \ldots \\
\text { with } \mathrm{S}_{1} \ldots \ldots \ldots \ldots \ldots \ldots\end{array}$ & $\begin{array}{l}65.7 \\
60.9\end{array}$ & 4.7 & 0.04 \\
\hline $\begin{array}{r}\text { Susceptible all lines } \mathrm{S}_{3} \ldots \ldots \ldots \ldots \ldots \ldots \ldots \ldots \\
\text { with } \mathrm{S}_{2} \ldots \ldots \ldots \ldots \ldots \ldots \ldots\end{array}$ & $\begin{array}{l}82.3 \\
65.7\end{array}$ & 52.6 & $<0.01$ \\
\hline $\begin{array}{r}\text { Susceptible all lines } \mathrm{S}_{5} \ldots \ldots \ldots \ldots \ldots \ldots \ldots \ldots \\
\text { with } \mathrm{S}_{4} \ldots \ldots \ldots \ldots \ldots \ldots \ldots\end{array}$ & $\begin{array}{l}76.6 \\
82.2\end{array}$ & 3.0 & 0.17 \\
\hline $\begin{array}{r}\text { Susceptible Line } 1 \mathrm{~S}_{1} \ldots \ldots \ldots \ldots \ldots \ldots \ldots \ldots \ldots \\
\qquad \text { with } \mathrm{U} \ldots \ldots \ldots \ldots \ldots \ldots \ldots\end{array}$ & $\begin{array}{l}87.5 \\
37.4\end{array}$ & 117.5 & $<0.01$ \\
\hline $\begin{array}{r}\text { Susceptible Line } 1 \mathrm{~S}_{2} \ldots \ldots \ldots \ldots \ldots \ldots \ldots \ldots \\
\qquad \text { with } \mathrm{S}_{1} \ldots \ldots \ldots \ldots \ldots \ldots \ldots\end{array}$ & $\begin{array}{l}83.3 \\
87.5\end{array}$ & 0.70 & 0.40 \\
\hline $\begin{array}{r}\text { Susceptible Line } 1 \mathrm{~S}_{\mathrm{z}} \ldots \ldots \ldots \ldots \ldots \ldots \ldots \ldots \\
\text { with } \mathrm{S}_{2} \ldots \ldots \ldots \ldots \ldots \ldots \ldots\end{array}$ & $\begin{array}{l}87.5 \\
83.5\end{array}$ & 0.85 & 0.40 \\
\hline $\begin{array}{r}\text { Susceptible Line } 1 \mathrm{~S}_{5} \ldots \ldots \ldots \ldots \ldots \ldots \ldots \ldots \\
\text { with } \mathrm{S}_{\mathbf{4}} \ldots \ldots \ldots \ldots \ldots \ldots \ldots\end{array}$ & $\begin{array}{l}79.6 \\
74.4\end{array}$ & 1.34 & 0.22 \\
\hline $\begin{array}{r}\text { Susceptible Line } 1 \mathrm{~S}_{6} \ldots \ldots \ldots \ldots \ldots \ldots \ldots \ldots \\
\text { with } \mathrm{S}_{5} \ldots \ldots \ldots \ldots \ldots \ldots\end{array}$ & $\begin{array}{l}82.5 \\
79.6\end{array}$ & 0.27 & 0.60 \\
\hline $\begin{array}{r}\text { Susceptible Line } 2 \mathrm{~S}_{\mathrm{t}} \ldots \ldots \ldots \ldots \ldots \ldots \ldots \ldots \\
\qquad \text { with } \mathrm{U} \ldots \ldots \ldots \ldots \ldots \ldots \ldots\end{array}$ & $\begin{array}{l}72.8 \\
37.4\end{array}$ & 28.8 & $<0.01$ \\
\hline $\begin{array}{r}\text { Susceptible Line } 2 \mathrm{~S}_{2} \ldots \ldots \ldots \ldots \ldots \ldots \ldots \ldots \\
\text { with } \mathrm{S}_{\mathrm{t}} \ldots \ldots \ldots \ldots \ldots \ldots \ldots\end{array}$ & $\begin{array}{l}83.5 \\
72.8\end{array}$ & 2.52 & 0.30 \\
\hline $\begin{array}{r}\text { Susceptible Line } 2 \mathrm{~S}_{3} \ldots \ldots \ldots \ldots \ldots \ldots \ldots \ldots \\
\text { with } \mathrm{S}_{2} \ldots \ldots \ldots \ldots \ldots \ldots \ldots\end{array}$ & $\begin{array}{l}79.3 \\
83.5\end{array}$ & 0.78 & 0.42 \\
\hline $\begin{array}{r}\text { Susceptible Line } 2 \mathrm{~S}_{5} \ldots \ldots \ldots \ldots \ldots \ldots \ldots \ldots \\
\qquad \text { with } \mathrm{S}_{4} \ldots \ldots \ldots \ldots \ldots \ldots \ldots\end{array}$ & $\begin{array}{l}72.6 \\
90.4\end{array}$ & 14.6 & $<0.01$ \\
\hline $\begin{array}{r}\text { Susceptible Line } 3 \mathrm{~S}_{1} \ldots \ldots \ldots \ldots \ldots \ldots \ldots \ldots \\
\text { with } \mathrm{U} \ldots \ldots \ldots \ldots \ldots \ldots \ldots\end{array}$ & $\begin{array}{l}70.6 \\
37.4\end{array}$ & 44.15 & $<0.01$ \\
\hline $\begin{array}{r}\text { Susceptible Line } 3 \mathrm{~s}_{2} \ldots \ldots \ldots \ldots \ldots \ldots \ldots \ldots \\
\text { with } \mathrm{S}_{1} \ldots \ldots \ldots \ldots \ldots \ldots \ldots\end{array}$ & $\begin{array}{l}77.4 \\
70.6\end{array}$ & 1.4 & 0.22 \\
\hline $\begin{array}{r}\text { Susceptible Line } 3 \mathrm{~S}_{3} \ldots \ldots \ldots \ldots \ldots \ldots \ldots \ldots \\
\text { with } \mathrm{S}_{2} \ldots \ldots \ldots \ldots \ldots \ldots \ldots\end{array}$ & $\begin{array}{l}79.3 \\
77.4\end{array}$ & 0.1 & 0.75 \\
\hline
\end{tabular}

* $S_{1}$ to $S_{6}=$ progeny tests on individuals of first to sixth selections.

$\dagger U=$ unselected mice. 


\begin{tabular}{|c|c|c|c|}
\hline \multirow{2}{*}{ Stocks compared } & \multirow{2}{*}{ Mortality } & \multicolumn{2}{|c|}{ Significance of differences } \\
\hline & & $x^{2}$ & $P$ \\
\hline & per cent & & \\
\hline $\begin{array}{r}\text { Susceptible Line } 4 S_{1} \ldots \ldots \ldots \ldots \ldots \ldots \ldots \ldots \\
\text { with } U \ldots \ldots \ldots \ldots \ldots \ldots \ldots\end{array}$ & $\begin{array}{l}46.7 \\
37.4\end{array}$ & 3.7 & 0.06 \\
\hline $\begin{array}{r}\text { Susceptible Line } 4 \mathrm{~S}_{2} \ldots \ldots \ldots \ldots \ldots \ldots \ldots \ldots \ldots \ldots \ldots \ldots \\
\text { with } \mathrm{S}_{1} \ldots \ldots \ldots \ldots \ldots \ldots \ldots\end{array}$ & $\begin{array}{l}77.9 \\
46.7\end{array}$ & 21.5 & $<0.01$ \\
\hline $\begin{array}{r}\text { Susceptible Line } 4 \mathrm{~S}_{8} \ldots \ldots \ldots \ldots \ldots \ldots \ldots \ldots \\
\text { with } \mathrm{S}_{2} \ldots \ldots \ldots \ldots \ldots \ldots \ldots\end{array}$ & $\begin{array}{l}48.0 \\
77.9\end{array}$ & 13.4 & $<0.01$ \\
\hline 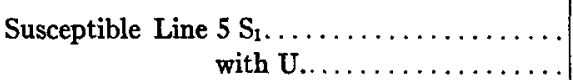 & $\begin{array}{l}50.0 \\
37.4\end{array}$ & 7.08 & $<0.01$ \\
\hline $\begin{array}{r}\text { Susceptible Line } 5 S_{2} \ldots \ldots \ldots \ldots \ldots \ldots \ldots \ldots \\
\text { with } S_{1} \ldots \ldots \ldots \ldots \ldots \ldots\end{array}$ & $\begin{array}{l}46.2 \\
50.0\end{array}$ & 0.49 & 0.50 \\
\hline $\begin{array}{r}\text { Susceptible Line } 5 S_{3} \ldots \ldots \ldots \ldots \ldots \ldots \ldots \ldots \ldots \ldots \ldots \ldots \\
\text { with } S_{2} \ldots \ldots \ldots \ldots \ldots \ldots\end{array}$ & $\begin{array}{l}60.0 \\
46.0\end{array}$ & 4.36 & 0.03 \\
\hline $\begin{array}{r}\text { Resistant all lines } R_{1} \ldots \ldots \ldots \ldots \ldots \ldots \ldots \ldots \\
\text { with } U \ldots \ldots \ldots \ldots \ldots \ldots \ldots \ldots\end{array}$ & $\begin{array}{l}20.1 \\
37.4\end{array}$ & 15.42 & $<0.01$ \\
\hline $\begin{array}{r}\text { Resistant all lines } R_{2} \ldots \ldots \ldots \ldots \ldots \ldots \ldots \ldots \ldots \ldots \ldots \ldots \\
\text { with } R_{1} \ldots \ldots \ldots \ldots \ldots \ldots \ldots\end{array}$ & $\begin{array}{l}11.3 \\
20.1\end{array}$ & 7.42 & $<0.01$ \\
\hline $\begin{array}{r}\text { Resistant all lines } \mathbf{R}_{4} \ldots \ldots \ldots \ldots \ldots \ldots \ldots \ldots \ldots \ldots \ldots \ldots \\
\text { with } \mathbf{R}_{3} \ldots \ldots \ldots \ldots \ldots \ldots \ldots\end{array}$ & $\begin{array}{l}17.5 \\
14.8\end{array}$ & 1.80 & 0.18 \\
\hline $\begin{array}{r}\text { Resistant Line } 1 R_{1} \ldots \ldots \ldots \ldots \ldots \ldots \ldots \ldots \\
\text { with } U \ldots \ldots \ldots \ldots \ldots \ldots \ldots\end{array}$ & $\begin{array}{l}16.0 \\
37.4\end{array}$ & 13.64 & $<0.01$ \\
\hline $\begin{array}{r}\text { Resistant Line } 1 \mathrm{R}_{2} \ldots \ldots \ldots \ldots \ldots \ldots \ldots \ldots \ldots \ldots \ldots \ldots \\
\text { with } \mathbf{R}_{1}, \ldots \ldots \ldots \ldots \ldots \ldots\end{array}$ & $\begin{array}{r}9.1 \\
16.0\end{array}$ & 3.30 & 0.07 \\
\hline $\begin{array}{r}\text { Resistant Line } 1 \mathbf{R}_{\mathbf{4}} \ldots \ldots \ldots \ldots \ldots \ldots \ldots \ldots \\
\text { with } \mathbf{R}_{\mathbf{s}} \ldots \ldots \ldots \ldots \ldots \ldots\end{array}$ & $\begin{array}{l}17.8 \\
15.6\end{array}$ & 1.12 & 0.25 \\
\hline $\begin{array}{r}\text { Resistant Line } 2 R_{1} \ldots \ldots \ldots \ldots \ldots \ldots \ldots \ldots \\
\text { with } U \ldots \ldots \ldots \ldots \ldots \ldots \ldots\end{array}$ & $\begin{array}{l}32.3 \\
37.4\end{array}$ & 0.31 & 0.52 \\
\hline $\begin{array}{r}\text { Resistant Line } 2 \mathbf{R}_{2} \ldots \ldots \ldots \ldots \ldots \ldots \ldots \ldots \\
\text { with } \mathbf{R}_{1} \ldots \ldots \ldots \ldots \ldots \ldots \ldots\end{array}$ & $\begin{array}{l}20.0 \\
32.3\end{array}$ & 2.07 & 0.15 \\
\hline $\begin{array}{r}\text { Resistant Line } 2 \mathrm{R}_{\mathbf{1}} \ldots \ldots \ldots \ldots \ldots \ldots \ldots \ldots \ldots \ldots \ldots \ldots \ldots \\
\text { with } \mathbf{R}_{\mathbf{s}} \ldots \ldots \ldots \ldots \ldots \ldots \ldots\end{array}$ & $\begin{array}{l}15.5 \\
10.1\end{array}$ & 1.29 & 0.22 \\
\hline with $R_{1} \ldots \ldots \ldots \ldots \ldots \ldots$ & 32.3 & 4.28 & 0.04 \\
\hline with $U . . . \ldots \ldots \ldots \ldots \ldots \ldots$ & 37.4 & 15.92 & $<0.01$ \\
\hline
\end{tabular}

Lexion ratio formula. In Table VIII the results on susceptible Lines 1 and 2 and resistant Lines $1 \mathrm{~A}, 1 \mathrm{~B}$, and $1 \mathrm{C}$ are given. Litters in susceptible Line 2 did not tend, and litters in susceptible Line 1 and 
TABLE VIII

Homogeneily of Selected Lines

\begin{tabular}{|c|c|c|c|c|c|}
\hline Line & Selection: & No. of litters & $L$ & $x^{2}$ & $p$ \\
\hline \multirow[t]{5}{*}{$S_{1}$} & 1 & 24 & 1.80 & 78.0 & $<0.01$ \\
\hline & 2 & 18 & 1.77 & 23.0 & 0.02 \\
\hline & 3 & 65 & 1.82 & 193.1 & $<0.01$ \\
\hline & 4 & 129 & 1.26 & 43.4 & 0.02 \\
\hline & 5 & 54 & 1.03 & 58.3 & 0.65 \\
\hline \multirow[t]{5}{*}{$\mathrm{S}_{\mathbf{2}}$} & 1 & 11 & 1.53 & 11.80 & 0.02 \\
\hline & 2 & 22 & 1.34 & 39.60 & $<0.01$ \\
\hline & 3 & 31 & 1.16 & 43.20 & 0.17 \\
\hline & 4 & 124 & 1.20 & 39.42 & 0.05 \\
\hline & 5 & 41 & 1.33 & 65.86 & $<0.01$ \\
\hline White-face & $1-4$ & 54 & 1.14 & 70.74 & 0.12 \\
\hline Black-and-tan & $1-4$ & 31 & 1.06 & 35.03 & 0.20 \\
\hline $\mathbf{R}_{1} \mathbf{A}$ & $1-5$ & 138 & 1.28 & 227.7 & $<0.01$ \\
\hline \multirow[t]{5}{*}{$870^{7} \times 133 \%$} & 1 & 2 & - & - & $*$ \\
\hline & 2 & 14 & 0.87 & 10.7 & 0.70 \\
\hline & 3 & 59 & 1.34 & 86.7 & $<0.01$ \\
\hline & 4 & 54 & 1.31 & 93.9 & $<0.01$ \\
\hline & 5 & 9 & 1.31 & 15.6 & 0.05 \\
\hline $\mathbf{R}_{\mathbf{1}} \mathrm{B}$ & 4 & 14 & 0.95 & 12.7 & 0.40 \\
\hline \multirow[t]{2}{*}{87 or $^{\prime} 35$ \% } & 3 & 32 & 1.14 & 41.6 & 0.22 \\
\hline & 2 & 15 & 0.86 & 11.2 & 0.70 \\
\hline $\mathrm{R}_{\mathbf{1}} \mathrm{C}$ & 1 & 3 & - & - & * \\
\hline \multirow[t]{3}{*}{$87 \sigma^{7} \times 97$ 웅 } & 2 & 12 & 1.17 & 16.68 & 0.10 \\
\hline & 3 & 19 & 1.08 & 22.4 & 0.20 \\
\hline & 4 & 24 & 1.15 & 32.1 & 0.10 \\
\hline
\end{tabular}

* 0 per cent mortality.

resistant Line $1 \mathrm{~A}$ did tend toward uniformity on repeated selection. The remaining lines, resistant $1 \mathrm{~B}$ and $1 \mathrm{C}$, and susceptible white-face and black-and-tan, ${ }^{2}$ were relatively homogeneous at the first selection and have continued so.

2 The susceptible white-face and black-and-tan strains are described in the next paragraph. 
Special Strains of Susceptible Mice.-Lines of mice brother to sister inbred for many generations were tested, together with the Rockefeller Institute selected and unselected control lines, at the same time and

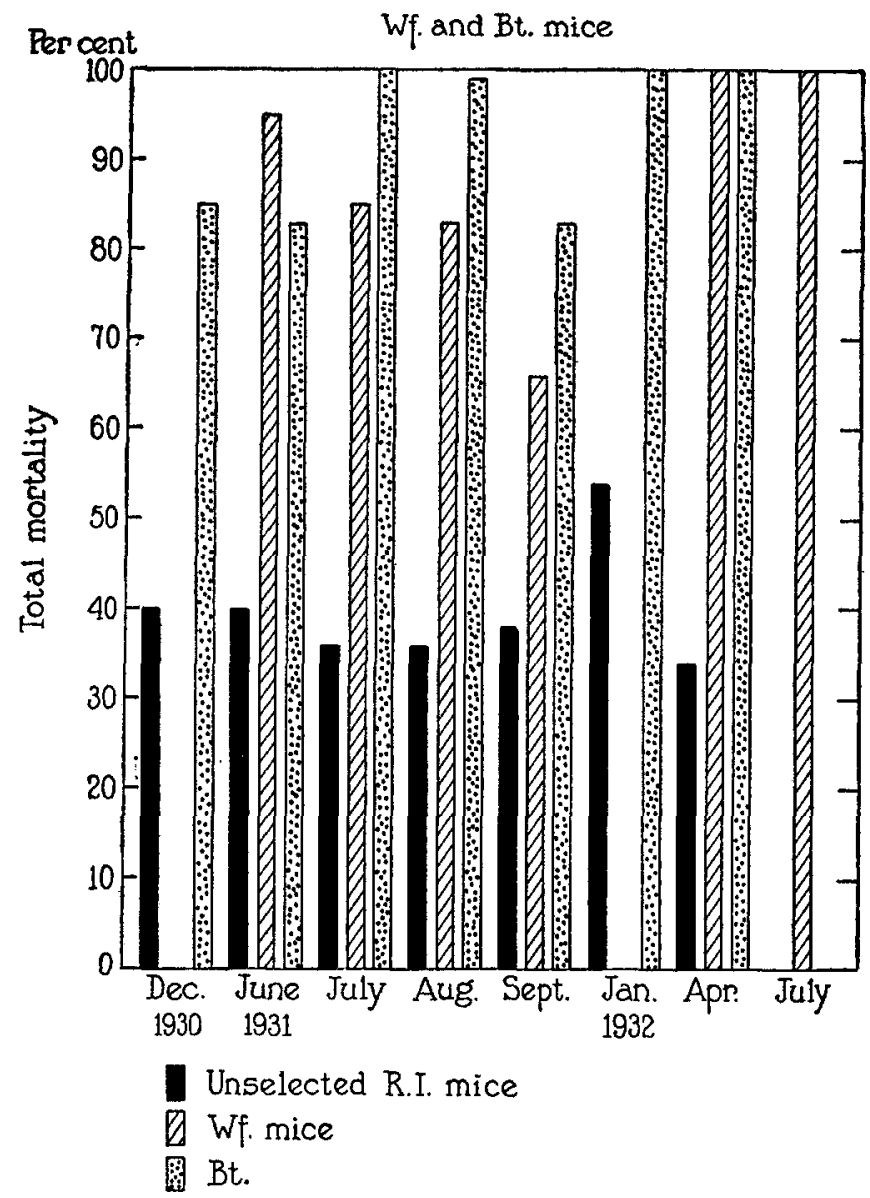

TeXr-FIg. 2. Comparative mortalities of unselected R. I. mice and white-face and black-and-tan mice following intrastomachal instillation of $B$. enteritidis mouse typhoid bacilli.

with the same culture. Table IX and Text-fig. 2 show the results of these tests. In Table $\mathrm{X}$ the total mortalities of different lines are compared according to the $\chi^{2}$ test. Rockefeller Institute, hairless, 
TABLE IX

Relative Susceptibility of Special Strains of Mice to Intrastomachal Instillation of Enteritidis Mouse Typhoid Bacilli

\begin{tabular}{|c|c|c|c|c|}
\hline Strain of mice & No. of tests & $\begin{array}{l}\text { Total No. } \\
\text { tested }\end{array}$ & $\begin{array}{c}\text { Total No. } \\
\text { dead }\end{array}$ & Dead \\
\hline & & & & per cent \\
\hline Bagg. $\ldots \ldots \ldots \ldots \ldots \ldots \ldots \ldots \ldots$ & 8 & 452 & 104 & 23.0 \\
\hline Hairless $\ldots \ldots \ldots \ldots \ldots \ldots \ldots \ldots \ldots \ldots$ & 3 & 166 & 52 & 31.3 \\
\hline 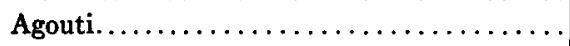 & 4 & 69 & 13 & 18.8 \\
\hline Pink-eye. $\ldots \ldots \ldots \ldots \ldots \ldots \ldots \ldots \ldots \ldots$ & 2 & 36 & 7 & 19.4 \\
\hline Dwarf $\ldots \ldots \ldots \ldots \ldots \ldots \ldots \ldots$ & 2 & 32 & 9 & 28.1 \\
\hline Spotted................. & 2 & 8 & 7 & 87.5 \\
\hline Black-and-tan unselected. . . . . . . . . . . & 6 & 100 & 43 & 43.0 \\
\hline Black-and-tan selected $\ldots \ldots \ldots \ldots \ldots$ & 9 & 117 & 113 & 96.5 \\
\hline White-face unselected . . . . . . . . . . . . & 7 & 164 & 146 & 89.0 \\
\hline
\end{tabular}

TABLE $X$

Significance of Differences in Mortality of Strains of Mice

\begin{tabular}{|c|c|c|c|c|}
\hline \multirow{2}{*}{\multicolumn{2}{|c|}{ Stocks compared }} & \multirow{2}{*}{ Mortality } & \multicolumn{2}{|c|}{$\begin{array}{l}\text { Significance of } \\
\text { differences }\end{array}$} \\
\hline & & & $x^{2}$ & $\boldsymbol{p}$ \\
\hline & & percent & & \\
\hline \multicolumn{2}{|c|}{ R. I. unselected . . . . . . } & 37.4 & & \\
\hline with & Bagg . . . . . . . . . . . . . . . & 23.0 & 26.5 & $<0.01$ \\
\hline “ & hairless $\ldots \ldots \ldots \ldots \ldots \ldots \ldots \ldots$ & 31.0 & 2.1 & 0.15 \\
\hline “ & agouti. . . . . . . . . . . . & 19.0 & 9.4 & $<0.01$ \\
\hline “ & pink-eye $\ldots \ldots \ldots \ldots \ldots \ldots \ldots$ & 27.0 & 4.8 & 0.03 \\
\hline “ & dwarf $\ldots \ldots \ldots \ldots \ldots \ldots \ldots$ & 28.0 & 1.1 & 0.30 \\
\hline " & spotted $\ldots \ldots \ldots \ldots \ldots \ldots \ldots \ldots$ & 87.5 & 8.0 & $<0.01$ \\
\hline “ & white-face $\ldots \ldots \ldots \ldots \ldots \ldots \ldots$ & 89.0 & 144.8 & $<0.01$ \\
\hline “ & black-and-tan selected . . . . . . . . . & 97.0 & 143.0 & $<0.01$ \\
\hline “ & black-and-tan unselected . . . . . . . . . & 43.0 & 1.1 & 0.30 \\
\hline \multicolumn{5}{|l|}{ Bagg. . } \\
\hline with & hairless. . . . . . . . & & 4.31 & 0.04 \\
\hline “ & agouti............. & & 0.5 & 0.50 \\
\hline$"$ & pink-eye. . . . . . . . & & 0.2 & 0.65 \\
\hline “ & dwarf $\ldots \ldots \ldots \ldots \ldots$ & & 0.4 & 0.50 \\
\hline " & spotted.................. & & 16.9 & $<0.01$ \\
\hline “ & white-face $\ldots \ldots \ldots \ldots \ldots \ldots \ldots \ldots$ & & 217.2 & $<0.01$ \\
\hline$" “$ & black-and-tan selected . . . . . . . . . & & 212.6 & $<0.01$ \\
\hline “ & black-and-tan unselected $\ldots \ldots \ldots \ldots$ & & 16.5 & $<0.01$ \\
\hline
\end{tabular}


dwarf, and unselected black-and-tan mice did not differ significantly; likewise, Bagg and pink-eye belonged in the hairless, dwarf, and unselected black-and-tan group. White-face, selected black-and-tan, and spotted strains, however, showed significantly higher mortalities, $P=<0.01$. These differences were consistent in repeated tests.

\section{Cross-Breeding Test}

The susceptible white-face strain, relatively homogeneous and stable, with 89 per cent average mortality, was mated with the selected resistant Rockefeller Institute strain, $1 \mathrm{~A}$, relatively stable but not homogeneous, with 15 per cent average mortality. The resulting $F_{1}$ progeny were then back-crossed to both susceptibles and resistants and mated together for $F_{2}$ progeny. The $F_{1}, F_{2}$, and back-crossed progeny were tested simultaneously with a single culture administered according to the standard technique, thus eliminating possible variables associated with the testing of different batches at different times and insuring accurate information of the relative resistance of different lines to the natural infection. The $\mathrm{F}_{2}$ and back-cross progeny were of standard age -2 to 3 months; the $F_{1}$ progeny were 5 to 6 months old, well within the tested age limits of uniform susceptibility.

Dec. 14, 1931. Four males from the selected 85 per cent resistant Line 1 of the R. I. mice were mated each with three or four 90 per cent susceptible white-face line females, and four white-face males each with three or four resistant females. In the first instance, ten $F_{1}$ litters, totaling 52 progeny, resulted; in the second, eleven $F_{1}$ litters, totaling 72 progeny.

Apr. 2, 1932. Five males from different litters of $F_{1}$ (resistant male $x$ susceptible female) and five males from different litters of $F_{1}$ (susceptible male $x$ resistant female) progeny were mated back to susceptible and resistant mothers respectively. At the same time, ten $F_{1}$ females were back-crossed to two resistant sires and eighteen $F_{1}$ females to four susceptible sires. Finally, brother to sister matings were made of the remaining $F_{1}$ progeny,-four males to ten females from the (resistant male $\mathrm{x}$ susceptible female) group and seven males to nineteen females from the (susceptible male $\mathrm{x}$ resistant female) group.

July 1, 1932. All mice were given the standard intrastomachal instillation of $0.5 \mathrm{cc}$. broth containing $5,000,000 \mathrm{~B}$. enteritidis mouse typhoid bacilli. Twentyeight white-face susceptibles were likewise injected at the same time. The results are given in Table XI. 
All the white-face mice died. The original resistant mice were not fit for the test. Of $124 \mathrm{~F}_{1}$ progeny, 17.7 per cent died, indicating that resistance factors are dominant to those of susceptibility. The differences in mortality between the two groups of $F_{1}$ mice are not significant, $x^{2}=1.7, P=0.20$. Of 116 progeny from back-cross

\section{TABLE XI}

Relative Susceptibility of Progeny of $F_{1}, F_{2}$, and Back-Cross Matings of Selected Susceptible and Resistant Mice to Intrastomachal Instillation of B. enteritidis Mouse Typhoid Bacilli

\begin{tabular}{|c|c|c|c|c|c|}
\hline Line identification & Parentage & $\begin{array}{l}\text { No. } \\
\text { litters } \\
\text { tested }\end{array}$ & 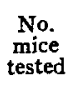 & $\begin{array}{c}\text { No. } \\
\text { dead }\end{array}$ & Dead \\
\hline $\begin{array}{l}\mathbf{F}_{1}(a) \\
\mathbf{F}_{1}(b)\end{array}$ & $\begin{array}{l}\mathrm{R} \sigma^{\top} \sigma^{\top} \times \mathrm{S} \% \text { } \\
\mathrm{S} \sigma^{7} \sigma^{7} \times \mathrm{R} \text { \% }\end{array}$ & $\begin{array}{l}10 \\
11\end{array}$ & $\begin{array}{l}52 \\
72\end{array}$ & $\begin{array}{l}12 \\
10\end{array}$ & $\begin{array}{l}\text { per cen } \\
23.0 \\
13.9\end{array}$ \\
\hline Totals......... & & 21 & 124 & 22 & 17.7 \\
\hline $\begin{array}{ccc}\text { Back-cross } & (a) \\
\text { “ } & \text { “ } & (b) \\
\text { “ } & \text { “ } & (c)\end{array}$ & 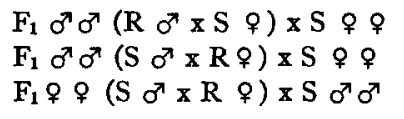 & $\begin{array}{l}7 \\
6 \\
6\end{array}$ & $\begin{array}{l}42 \\
28 \\
46\end{array}$ & $\begin{array}{l}23 \\
26 \\
22\end{array}$ & $\begin{array}{l}54.9 \\
93.0 \\
47.9\end{array}$ \\
\hline Totals......... & & 19 & 116 & 71 & 61.2 \\
\hline 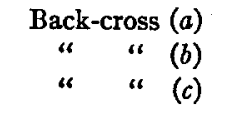 & 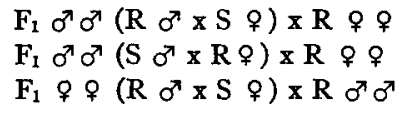 & $\begin{array}{l}6 \\
1 \\
8\end{array}$ & $\begin{array}{r}39 \\
8 \\
67\end{array}$ & $\begin{array}{r}9 \\
1 \\
20\end{array}$ & $\begin{array}{l}23.1 \\
12.5 \\
29.9\end{array}$ \\
\hline Totals........ & & 15 & 114 & 30 & 26.3 \\
\hline $\begin{array}{l}\mathbf{F}_{2}(a) \\
\mathbf{F}_{2}(b)\end{array}$ & $\begin{array}{l}F_{1}\left(\mathrm{R} 0^{7} \times \mathrm{S} \%\right) \\
\mathrm{F}_{1}\left(\mathrm{~S} 0^{\pi} \times \mathrm{R} \%\right)\end{array}$ & $\begin{array}{r}7 \\
19\end{array}$ & $\begin{array}{r}59 \\
133\end{array}$ & $\begin{array}{l}20 \\
46\end{array}$ & $\begin{array}{l}34.0 \\
34.5\end{array}$ \\
\hline Totals..... & & 26 & 192 & 66 & 34.2 \\
\hline
\end{tabular}

$\mathrm{R}=$ resistant. $\mathrm{S}=$ susceptible.

matings of $F_{1}$ to susceptibles, 61.2 per cent died. The differences in mortality between the three groups comprising this set are significant and at present must be ascribed to differences in the original material. Of 114 progeny from the back-cross matings of $F_{1}$ to resistants, 26.3 per cent died. The difference in mortality between this group, 26.3 per cent, and that from the the $F_{1}$ to susceptible back-cross matings, 
61.2 per cent, is significant. The differences in mortality between the three groups comprising this set are not significant. Finally, of 192 progeny of $F_{2}$ generation, 34.2 per cent died. Analysis of mortalities in $F_{1}, F_{2}$, and back-cross progeny according to color marking showed no consistent association between the white-face color pattern and susceptibility. Comparisons of sex mortalities in each of the ten sets give no evidence of sex linkage. Taken together the results of this experiment are evidence that definite amounts of resistance to natural $B$. enteritidis infection are inherited, dominant, and not color nor sexlinked.

A final and necessary test of the relative resistance of these lines of mice was made by exposing them to a herd infection.

Experiment 1.-Oct. 15, 1931. Twenty unselected control, R. I. mice were each given an intrastomachal instillation of 5,000,000 B. enteritidis bacilli. They were then placed in four cages, five mice per cage. 24 hours later they were changed to fresh cages and to each cage of five injected mice, five selected susceptible and five selected resistants of the $R$. I. line were added as healthy contacts. Bedding was changed weekly thereafter. Postmortem studies were made on dead mice unless destroyed by cannibalism. Since infections other than B. enteritidis typhoid were not encountered, total mortality figures are used to represent mouse typhoid mortality. The results at 8 weeks are given in Table XII. In each of the four communities the mortality of the susceptible contacts surpassed that of the resistant contacts. 30 per cent of the twenty susceptibles died, as compared to 0 per cent of the resistant contacts.

Experiment 2.-Nov. 9, 1931. Twenty selected susceptible R. I. mice were each given the standard instillation of $B$. enteritidis and placed in four cages of five mice each. 24 hours later five susceptible and five resistant R. I. mice were added to each cage as contacts. Further procedures were similar to those in Experiment 1. In each community the mortality of susceptible was greater than that of resistant contacts; the total mortality of the former was 65 per cent as compared to 15 per cent of the latter (Table XII).

Experiment 3.- Jan. 12, 1932. Mice were assembled and treated as in Experiment 2 (Table XII). In each cage the mortality of susceptible contacts exceeded that of resistant contacts; of the susceptibles, 85 per cent, and of the resistants, 20 per cent died.

Experiment 4.-Feb. 2, 1932. Mice were assembled in ten cages, the first six containing five susceptible and five resistant R. I. mice as contacts, Cages 7 and 8 , white-face susceptible and resistant R. I. mice, and Cages 9 and 10, black-and-tan susceptible and resistant R. I. mice as contacts (Table XII). In two cages, no mortality occurred among the contacts; in one cage the mortality of susceptible contacts equalled, and in seven cages surpassed that of the resistant contacts. 38 per cent of the susceptible and 8 per cent of the resistant contacts succumbed. 
TABLE XII

Comparative Mortalities of Susceptible and Resistant Strains When Exposed to Spontaneous Herd Infection (B. enteritidis Mouse Typhoid)

\begin{tabular}{|c|c|c|c|c|c|c|c|}
\hline \multirow{2}{*}{$\begin{array}{l}\text { Experiment } \\
\text { No. }\end{array}$} & \multirow{2}{*}{ Case No. } & \multicolumn{2}{|c|}{ Mice injected } & \multicolumn{2}{|c|}{ Susceptible contacts } & \multicolumn{2}{|c|}{ Resistant contacts } \\
\hline & & No. & Dead & No. & Dead & No. & Dead \\
\hline \multirow{5}{*}{1} & & & per cent & & per cent & & per cent \\
\hline & 1 & 5 & 20 & 5 & 20 & 5 & 0 \\
\hline & 2 & 5 & 0 & 5 & $\mathbf{0}$ & 5 & 0 \\
\hline & 3 & 5 & 40 & 5 & 40 & 5 & 0 \\
\hline & 4 & 5 & 60 & 5 & 60 & 5 & $\mathbf{0}$ \\
\hline \multirow[t]{4}{*}{2} & 1 & 5 & 100 & 5 & 80 & 5 & 0 \\
\hline & 2 & 5 & 100 & 5 & 40 & 5 & 0 \\
\hline & 3 & 5 & 100 & 5 & 100 & 5 & 20 \\
\hline & 4 & 5 & 100 & 5 & 60 & 5 & 40 \\
\hline \multirow[t]{4}{*}{3} & 1 & 5 & 100 & 5 & 80 & 5 & 0 \\
\hline & 2 & 5 & 60 & 5 & 100 & 5 & 0 \\
\hline & 3 & 5 & 100 & 5 & 60 & 5 & 20 \\
\hline & 4 & 5 & 100 & 5 & 100 & 5 & 80 \\
\hline \multirow[t]{10}{*}{4} & 1 & 5 & 80 & 5 & 20 & 5 & 0 \\
\hline & 2 & 5 & 80 & 5 & 20 & 5 & 0 \\
\hline & 3 & 5 & 80 & 5 & 0 & 5 & 0 \\
\hline & 4 & 5 & 80 & 5 & 60 & 5 & 20 \\
\hline & 5 & 5 & 100 & 5 & 80 & 5 & 40 \\
\hline & 6 & 5 & 100 & 5 & 60 & 5 & 0 \\
\hline & 7 & 5 & 80 & 5 & 20 & 5 & 0 \\
\hline & 8 & 5 & 100 & 5 & 0 & 5 & 0 \\
\hline & 9 & 5 & 40 & 5 & 100 & 5 & 0 \\
\hline & 10 & 5 & 100 & 5 & 20 & 5 & 20 \\
\hline \multirow[t]{12}{*}{5} & 1 & 5 & 100 & 5 & 100 & 5 & 60 \\
\hline & & & & 4 & 100 & - & - \\
\hline & & & & 3 & 100 & 3 & 66 \\
\hline & 2 & 5 & 100 & 5 & 100 & 5 & 0 \\
\hline & & & & 4 & 100 & - & - \\
\hline & & & & 3 & 100 & 3 & 0 \\
\hline & 3 & 5 & 100 & 5 & 100 & 5 & 0 \\
\hline & & & & 4 & 100 & - & - \\
\hline & & & & 3 & 100 & 3 & 33 \\
\hline & 4 & 5 & 100 & 5 & 100 & 5 & 20 \\
\hline & & & & 4 & 100 & - & - \\
\hline & & & & 3 & 100 & 3 & 66 \\
\hline
\end{tabular}


TABLE XII-Concluded

\begin{tabular}{|c|c|c|c|c|c|c|c|}
\hline \multirow{2}{*}{$\begin{array}{l}\text { Experiment } \\
\text { No. }\end{array}$} & \multirow{2}{*}{ Cage No. } & \multicolumn{2}{|c|}{ Mice injected } & \multicolumn{2}{|c|}{ Susceptible contacts } & \multicolumn{2}{|c|}{ Resistant contacts } \\
\hline & & No. & Dead & No. & Dead & No. & Dead \\
\hline \multirow{11}{*}{ 5-concluded } & & & per cent & & per cent & & per cent \\
\hline & 5 & 5 & 100 & 5 & 100 & 5 & 0 \\
\hline & & & & 4 & 100 & 一 & - \\
\hline & & & & 3 & 33 & 3 & 0 \\
\hline & 6 & 5 & 100 & 5 & 100 & 5 & 0 \\
\hline & & & & 4 & 100 & - & - \\
\hline & & & & 3 & 66 & 3 & 66 \\
\hline & 7 & 5 & 100 & 5 & 100 & 5 & 20 \\
\hline & & & & 4 & 100 & & \\
\hline & & & & 3 & 100 & 3 & 33 \\
\hline & & & & 194 & 70 & 166 & 12 \\
\hline
\end{tabular}

Experiment 5.-Apr. 13, 1932. A similar test was run with Cages 1 to 5, made up of susceptible and resistant R. I. contacts, and Cages 6 and 7 of susceptible, white-face, and resistant R. I. contacts. Apr. 28, 1932, four black-and-tan susceptibles were added as healthy contacts to each of the seven cages, and May 17,1932 , three susceptible and three resistant $R$. I. mice were added to each cage. Mortalities at the end of the experiment, June 30,1932, are given in Table XII. In one of the fourteen tests, the mortality of susceptible contacts equalled, and in thirteen surpassed that of the resistant contacts. 81 of the total 84 susceptible contacts succumbed, 96 per cent, as contrasted with 8 of the 56 resistant contacts, 14 per cent.

Of the five experiments, three were run in four, one in ten, and one in fourteen simultaneous tests. Of the 194 susceptible contacts, 70 per cent died, as compared to 12 per cent of the resistant contacts, $\chi^{2}=$ 123.0, $P=<0.01$. In three of the total thirty-six tests, no susceptible and no resistant contacts died; in two tests, the mortality of the susceptibles equalled that of the resistants; in the remaining thirty-two tests, the death rate of the susceptible surpassed that of the resistant contacts. To summarize, selected mice susceptible to an experimental infection which closely approximates the natural one, were equally susceptible to the infection arising under herd conditions, and conversely, selected mice resistant to the experimental infection were correspondingly resistant to the natural one. 
DISCUSSION

Individuals of a random lot of mice in which known environmental variables have been controlled have been found to differ in their response to a uniform exposure to a natural infection. These differences, according to experimental evidence, are associated directly with heredity factors. The evidence as here presented is that progeny of animals dying soon after exposure suffer a higher mortality than progeny of animals surviving exposure. On the same basis of selection, lines with maximum, minimum, and intermediate mortality were obtained, indicating that selection per se did not direct the process. Again, inbreeding was carried out in both high-mortality and lowmortality lines and hence could not have exerted a directing influence on the process. The differences in mortality of selected lines are significant and have persisted through subsequent generations and have been measured. Again, lines with high mortality crossed with low-mortality lines yielded low-mortality $F_{1}$ mice; $F_{1}$ mice back-crossed with low-mortality mice yielded progeny with low mortality, and $F_{1}$ mice back-crossed with high-mortality mice yielded progeny with high mortality-demonstrating segregation of susceptibility and resistance factors on the basis of heredity. It becomes necessary, therefore, to regard the response of previously unexposed individuals to the mouse strain of $B$. enteritidis as dependent upon quantitative amounts of inherited resistance. The number of factors involved is not known because the material is not entirely homogeneous; apparently different combinations of multiple factors, one or more of which may be dominant, or partially so, are concerned. The relation of sex, fertility, and weight to inherent resistance is treated elsewhere (14). Whether the resistance is local or general, affected by environmental conditions, as, e.g., diet, and by acquired immunity which follows exposure to infection, and finally, how these inherited and acquired components of resistance together affect the response of the host to infection are matters now under investigation.

\section{CONCLUSIONS}

1. A colony of inbred mice has been established free from intercurrent infections and from the influence of extraneous variables 
detrimental to a study of their resistance to natural infection. A technique of measuring the resistance of mice to natural $B$. enteritidis mouse typhoid infection has been developed.

2. The Rockefeller Institute albino strain showed an average 37.4 per cent mortality to $B$. enteritidis mouse typhoid infection.

3. By breeding from progeny of mice dying early after exposure, lines approximately 85 per cent susceptible were obtained; by breeding from unexposed progeny of mice surviving infection, lines 15 per cent susceptible were obtained. Further selection within the most susceptible and most resistant lines did not alter their reaction; selection within the less susceptible and less resistant lines increased the sought factor. These rates remained approximately the same when the susceptibles received $1 / 100$ th and the resistants ten times the standard dose. The selected mice reacted consistently when exposed to spontaneous herd infection.

4. Several strains of mice, brother to sister inbred for special factors, did not differ materially in susceptibility. White-face and selected black-and-tan strains, however, proved 89.0 and 97 per cent susceptible.

5. White-face susceptibles mated with resistant Rockefeller Institute mice gave $F_{1}$ progeny, 17.7 per cent susceptible. $F_{1}$ mice backcrossed to susceptibles gave progeny 61.2 per cent susceptible and back-crossed with resistants gave progeny 26.3 per cent susceptible. $\mathrm{F}_{2}$ mice mated inter se gave progeny 34.2 per cent susceptible. The results indicate that resistance factors are dominant and not sexlinked.

\section{REFERENCES}

1. Tyzzer, E. E., J. Med. Research, 1917, 37, 307.

2. Hagedoorn-La Brand, A. C., and Hagedoorn, A. L., Am. Naturalist., 1920, 69, 336.

3. Wright, S., and Lewis, P. A., Am. Naturalist, 1921, 55, 20.

4. Frateur, J. L., Tr. World's Poultry Cong., 1924, 2, 68.

5. Roberts, E., and Card, L. E., Poultry Science, 1926, 6, 18.

6. Lambert, W. V., and Knox, C. W., Anat. Rec., 1927, 37, 174; J. Immunol., 1932, 23, 229.

7. Irwin, M. R., Genetics, 1929, 14, 337.

8. Schott, R. G., Genetics, 1932, 17, 203. 
9. Pritchett, I. W., J. Exp. Med., 1925, 41, 195; 1926, 43, 161.

10. Webster, L. T., J. Exp. Med., 1930, 62, 931.

11. Webster, L. T., J. Exp. Med., 1930, 52, 909.

12. Webster, L. T., J. Exp. Med., 1924, 39, 879; 1925, $42,1$.

13. Fisher, R. A., Statistical methods for research workers, Edinburgh, Oliver and Boyd, 4th edition, 1932.

14. Webster, L. T., J. Exp. Med., 1933, 57, 819. 